\title{
COMPARISON OF INVASIVE VERSUS NON-INVASIVE ELECTRICAL EAR STIMULATION IN TINNITUS SUPPRESSION: LITERATURE REVIEW
}

\section{Shikha Spencer ${ }^{1 A B C D E F}$, Magdalena Sereda ${ }^{2,3 A B C D E F}$, Stefan Schoisswohl ${ }^{4 B C F}$, Jurek Olszewski ${ }^{\text {ADE }}$, Marzena Mielczarek ${ }^{\text {ACDEF }}$}

${ }^{1}$ Department of Otolaryngology, Laryngological Oncology, Audiology and Phoniatrics, Medical University of Lodz, Lodz, Poland

${ }^{2}$ Hearing Sciences, Division of Clinical Neuroscience, School of Medicine,

University of Nottingham, Nottingham, UK

${ }^{3}$ National Institute for Health Research (NIHR), Nottingham Biomedical Research

Centre, Nottingham, UK

${ }^{4}$ Department of Psychiatry and Psychotherapy, University of Regensburg, Regensburg, Germany

Corresponding author: Marzena Mielczarek, Medical University of Lodz, 90-549 Lodz, 113 Zeromskiego St, Poland; email: marzena.mielczarek@umed.lodz.pl, tel. $+42-6393581$

\begin{abstract}
Background: This paper is a review of the literature on electrical stimulation of the ear to treat tinnitus. This method of treatment has been used since the 1970s and different techniques have been explored. The primary aim of this work was to review the literature on electrical stimulation of the ear to suppress tinnitus, with a specific focus on the methods and stimulation parameters used so far and the efficacy of the different methods. A secondary aim was to formulate recommendations on electrical ear stimulation parameters that suppress tinnitus.

Material and methods: Four databases were searched: PubMed, Ovid Embase, Web of Science, and Science Direct. Database searches were conducted during November 2018 using the search terms: tinnitus and electrical stimulation. Inclusion criteria: All research articles on invasive and non-invasive electrical stimulation of the ear for suppressing tinnitus were included. Other inclusion criteria were records in English and involving adult human participants. Exclusion criteria: Studies on intracochlear stimulation using cochlear implants and studies where stimulation extended beyond the ear (e.g. transcutaneous electrical nerve stimulation, TENS) were excluded.

Results: Twenty publications met the inclusion criteria and were analysed in this review. A comparison was made between invasive and non-invasive electrical ear stimulation in terms of efficacy, type of current used, laterality of stimulation, intensity and frequency of the current, duration of tinnitus suppression, and adverse effects. Due to the non-standardised methodology of the studies, there was only a low level of evidence available in terms of the advantages of a particular technique or stimulation parameter. The difficulties in comparing the effectiveness of the studies were related to many factors, and these are discussed. One factor is the variability in outcome measures, including different definitions of treatment success and limited use of standardised or validated outcome measures.

Conclusions: Based on the reviewed literature, it is concluded there is no clear advantage of one stimulation condition over the other in terms of method, stimulation parameter, or effectiveness. This leads us to conclusion that the present body of evidence is insufficient to formulate definite recommendations for electrical ear stimulation.
\end{abstract}

Key words: tinnitus • electrical ear stimulation direct current $\bullet$ alternating current

\section{COMPARACIÓN DE LA ESTIMULACIÓN ELÉCTRICA INVASIVA Y NO INVASIVA DEL OÍDO EN EL TRATAMIENTO DEL TINNITUS.} REVISIÓN DE LA LITERATURA

\section{Resumen}

Introducción: Este artículo es una revisión de las publicaciones disponibles sobre la estimulación eléctrica del oído en el tratamiento del tinnitus subjetivo. El objetivo principal de la revisión es analizar las técnicas de estimulación utilizadas hasta ahora, teniendo en cuenta los parámetros utilizados y su efectividad. El segundo objetivo es intentar formular recomendaciones sobre técnicas y parámetros de estimulación eléctrica del oído en el tratamiento del tinnitus.

Material y métodos: Bases de datos utilizadas: PubMed, Ovid Embase, Web of Science y Science Direct. La búsqueda en las bases de datos se realizó en noviembre de 2018 utilizando las palabras clave: tinnitus y electroestimulación. 
Criterios de inclusión: se incluyeron los trabajos que tratan sobre la estimulación eléctrica invasiva y no invasiva del oído en el tratamiento del tinnitus, en grupos de pacientes adultos, publicados en inglés.

Criterios de exclusión: se excluyeron los estudios sobre la estimulación coclear con implantes cocleares y los estudios en los que la estimulación fue más allá del oído (por ejemplo, la estimulación nerviosa eléctrica transcutánea - ENET).

Resultados: De todas las publicaciones obtenidas, veinte cumplieron los criterios de inclusión y en base a estos se realizó el análisis. La comparación de la estimulación eléctrica del oído invasiva y no invasiva se realizó en términos de técnica de estimulación, efectividad del método, tipo de corriente utilizada, su intensidad y frecuencia, duración de la estimulación, así como efectos terapéuticos y efectos secundarios.

Debido a que la gran mayoría de estudios siguen una metodología de investigación no estándar, no hay mucha evidencia para demostrar las ventajas claras de las técnicas o parámetros de estimulación específicos. Son muchos factores que influyen en la dificultad de comparar la efectividad de los métodos individuales. Uno de ellos es la variedad de métodos para medir los resultados del tratamiento, incluidas las diferencias en la definición de la efectividad de la terapia utilizada o el uso limitado de métodos de medición estandarizados.

Resumen: En base a la literatura analizada, no se puede evidenciar superioridad en la efectividad en ninguno de los métodos de estimulación en comparación con los otros. Esto lleva a la conclusión adicional de que los datos de la literatura actual no son suficientes para formular recomendaciones sobre técnicas y parámetros de estimulación eléctrica del oído en el tratamiento del tinnitus.

Palabras clave: tinnitus • estimulación eléctrica del oído • corriente continua • corriente alterna • revisión de literatura

\title{
СРАВНИТЕЛЬНЫЙ АНАЛИЗ ИНВАЗИВНОЙ И НЕИНВАЗИВНОЙ ЭЛЕКТРОСТИМУЛЯЦИИ УХА ПРИ ЛЕЧЕНИИ УШНЫХ ШУМОВ. ОБЗОР ЛИТЕРАТУРЫ
}

\begin{abstract}
Аннотация
Введение: Статья представляет собой обзор доступных публикаций по теме электрической стимуляции уха при лечении субъективного ушного шума. Основная цель обзора состояла в том, чтобы проанализировать доступные методы стимуляции с учетом используемых параметров и их эффективности. Второй целью являлась попытка сформулировать рекомендации относительно методов и параметров электрической стимуляции слуха при лечении ушного шума.

Материалы и методы: спользуемые базы данных: PubMed, Ovid Embase, Web of Science и Science Direct. Поиск в базе данных проводился в ноябре 2018 года по ключевым словам: ушной шум и электростимуляция.

Критерии включения: работы по инвазивной и неинвазивной электрической стимуляции уха при лечении ушного шума, в группе взрослых пациентов, язык публикаций - английский.

Критерии исключения: обзор исключает исследования, касающиеся стимуляции улитки с помощью кохлеарных имплантатов, и исследования, в которых стимуляция выходила за пределы уха (например, электрическая стимуляция нерва через кожу - TENS).

Результаты: Из всех доступных публикаций двадцать соответствовали критериям включения. На их основе был проведен анализ. Сравнение инвазивной и неинвазивной электростимуляции уха проводилось с точки зрения техники стимуляции, эффективности метода, типа используемого тока, его интенсивности и частоты, продолжительности стимуляции, а также терапевтического эффекта и побочных эффектов.

В связи с нестандартной методологией исследования, нет достаточного количества доказательств, свидетельствующих о явных преимуществах конкретных методов или параметров стимуляции. Сложно сравнить эффективность отдельных методов по многим причинам. Одной из них является разнообразие методов опеределения результатов лечения, включая различия в определении эффективности используемой терапии или ограниченное использование стандартизированных методов измерения.

Выводы: На основании проанализированной литературы был сделан вывод об отсутствии явного преимущества одного из используемых методов стимуляции по сравнению с другим. Это приводит к дальнейшим выводам о том, что в современной литературе не достаточно данных для постановки рекомендаций по методикам и параметрам электростимуляции уха при лечении ушного шума.
\end{abstract}

Ключевые слова: ушной шум • электростимуляция уха • постоянный ток • переменный ток • обзор литературы.

\section{PORÓWNANIE INWAZYJNEJ I NIEINWAZYJNEJ STYMULACJI ELEKTRYCZNEJ UCHA W LECZENIU SZUMÓW USZNYCH. PRZEGLĄD LITERATURY}

\section{Streszczenie}

Wstep: Artykuł stanowi przegląd dostepnych publikacji na temat stymulacji elektrycznych ucha w leczeniu subiektywnych szumów usznych. Głównym celem przeglądu była analiza stosowanych dotychczas technik stymulacji, z uwzględnieniem wykorzystywanych parametrów, oraz ich skuteczności. Drugim celem było podjęcie próby sformułowania rekomendacji dotyczących technik i parametrów elektrycznej stymulacji ucha w terapii szumów usznych.

Material i metody: Wykorzystane bazy danych: PubMed, Ovid Embase, Web of Science i Science Direct. Wyszukiwanie w bazach danych przeprowadzono w listopadzie 2018 r. z użyciem słów kluczowych: szumy uszne i elektrostymulacja. 
Kryteria włączenia: prace dotyczące inwazyjnej i nieinwazyjnej elektrycznej stymulacji ucha w leczeniu szumów usznych, w grupie dorosłych pacjentów, język publikacji - angielski.

Kryteria wykluczenia: z przeglądu zostały wyłączone badania dotyczące stymulacji ślimaka za pomocą implantów ślimakowych oraz badania, w których stymulacja wykraczała poza ucho (np. przezskórna elektryczna stymulacja nerwów - TENS).

Wnioski: Spośród wszystkich uzyskanych publikacji, dwadzieścia spełniło kryteria włączenia i na ich podstawie została przeprowadzona analiza. Porównanie inwazyjnej i nieinwazyjnej stymulacji elektrycznej ucha przeprowadzono pod względem techniki prowadzonej stymulacji, skuteczności metody, rodzaju zastosowanego prądu, jego natężenia i częstotliwości, czasu trwania stymulacji oraz efektu terapeutycznego i działań niepożądanych.

Ze względu na niestandardową metodologię badań nie ma wielu dowodów świadczących o wyraźnych zaletach konkretnych technik lub parametrów stymulacji. Na trudności w porównywaniu skuteczności poszczególnych metod wpływa wiele czynników. Jednym z nich jest różnorodność metod pomiaru wyników leczenia, w tym różnice w definiowaniu skuteczności zastosowanej terapii czy ograniczone stosowanie standaryzowanych metod pomiarów.

Podsumowanie: Na podstawie analizowanej literatury postawiono wniosek o braku wyraźnej przewagi skuteczności jednej ze stosowanych metod stymulacji względem innych. Prowadzi to do dalszych konkluzji, że obecne dane literaturowe nie są wystarczające do sformułowania rekomendacji dotyczących technik i parametrów stymulacji elektrycznej ucha w leczeniu szumów usznych.

Słowa kluczowe: szumy uszne • stymulacja elektryczna ucha • prąd stały • prąd przemienny • przegląd literatury

\section{Abbreviations}

ES - electrical stimulation

AC - alternating current

DC - direct current

VAS - visual analogue scale

THI - Tinnitus Handicap Inventory

TQ - Tinnitus Questionnaire

\section{Background}

Tinnitus is the phantom perception of sound in the absence of any corresponding external source [1]. Studies have shown that tinnitus is a common symptom, affecting about $10-15 \%$ of the adult population [2,3]. Many patients habituate to this phantom sound; nevertheless, in around $1-2 \%$ of tinnitus patients it has a major impact on the quality of life $[4,5]$. Those significantly affected by tinnitus are reported to suffer from psychological disorders such as anxiety and depression [6] and can face debilitating difficulties in activities of daily living [7].

Multiple factors are known to contribute to tinnitus generation and defining them is considered fundamental for a complete cure of tinnitus. Understanding the exact pathophysiological process of tinnitus generation is still a challenge; however, primary central pathology is increasingly suspected [8]. Spontaneous neural activity in the auditory cortex has been examined in the tinnitus population and compared to healthy individuals; it appears that hyperactivity at the central level (auditory cortex, brainstem, posteroventral cochlear nucleus, inferior colliculus) may have a direct causal relationship to tinnitus generation $[9,10]$. In most cases, tinnitus is associated with auditory dysfunction, in which there is deprivation of the auditory cortex from normal stimulation. This leads to an activation of sodium/potassium currents and hyperpolarization of neuronal cells in the auditory cortex. This is followed by dominance of delta $(<4 \mathrm{~Hz})$ over alpha $(8-12 \mathrm{~Hz})$ waves [11].

Electrical stimulations (ES) of the head, ear, cranial nerves, or auditory cortex are possible methods of tinnitus treatment. Neurostimulation therapies like transcranial direct or alternating current stimulation (tDCS, tACS) target abnormal neuronal activity at the central level to suppress tinnitus, while electrical stimulation of the ear may work by targeting the peripheral hearing system pathology which secondarily triggers changes at the central level [12].

Extracochlear electric stimulation can suppress tinnitus by affecting the polarization of the outer hair cells (OHC) and changing their length, causing wave-like movements of the basilar membrane $[13,14]$. This activation at the peripheral level may lead to changes in electric potentials at the central level resulting in tinnitus suppression [14].

Electrical ear stimulation can be performed using either invasive or non-invasive approaches. Invasive electrical ear stimulation involves incision or puncture of the tympanic membrane in order to directly stimulate the cochlea by placing the stimulating electrode on the promontory or the round window [15-17]. In non-invasive ES, the hearing organ is stimulated from a relatively far field by placing the stimulating electrode in the external ear canal or on the tympanic membrane [18].

Although studies on electrical ear stimulation have shown promising results in tinnitus treatment, not much work has been done to investigate the optimal parameters and techniques. What is more, most of the studies done in the past used non-standard devices, making replication of results difficult.

The primary aim of this work was to review the literature on electrical ear stimulation in suppression of tinnitus with a specific focus on the methods and stimulation parameters used so far and the efficacy of different methods of stimulation. A secondary goal was to formulate some recommendations for electrical ear stimulation parameters for suppression of tinnitus.

\section{Material and methods}

Inclusion criteria: All research articles on invasive and non-invasive electrical stimulation of the ear for tinnitus suppression were included in this review. Records in English and involving adult human participants were other inclusion criteria.

Exclusion criteria: Studies on intracochlear stimulation with the use of cochlear implants and studies where the site of stimulation was beyond the ear (e.g. transcutaneous electrical nerve stimulation, TENS) were excluded. 
Table 1. Inclusion and exclusion criteria for selection of articles

\begin{tabular}{ll}
\hline & - Intervention: Invasive and non-in- \\
& vasive ear electrical stimulation for \\
& tinnitus suppression \\
Inclusion criteria & - Language of published article: English \\
& - Human studies \\
& - Adult participants \\
\hline & - Studies of intracochlear stimulation \\
Exclusion criteria & using cochlear implants or studies \\
& where stimulation extended beyond \\
& the ear (e.g. transcutaneous electrical \\
& nerve stimulation, TENS) \\
\hline
\end{tabular}

Search strategy: Studies were identified from the results of electronic database searches. Four databases were searched: PubMed, Ovid Embase, Web of Science, and Science Direct. Database searches were conducted during November 2018 using the search terms Tinnitus AND Electrical Stimulation. Manual scans of the reference lists of the retrieved records were performed.

Selecting relevant records. Three authors (SSp, SSc, and MS) independently screened all titles and abstracts to determine eligibility for inclusion in the review. Records were carried forward for full text screening if at least one author requested it. Two authors (SSp, MS) independently screened full texts for inclusion in the review; disagreements were discussed until consensus was reached.

Data extraction: Data were extracted using a data extraction form which was designed specifically for the review, piloted on a subset of records, and revised before formal data extraction was undertaken. Data were extracted on study design, population, intervention, comparator, type of stimulation (invasive vs non-invasive), electrode placement, type of current used, current intensity, current frequency, duration of treatment, adverse effects, and main efficacy outcomes for tinnitus. Two authors (SSp, MS) independently extracted the data and any disagreements were discussed until consensus was reached.

\section{Results}

The searches identified 2114 records in the four databases: PubMed $(n=417)$, Ovid Embase $(n=223)$, Science Direct $(n=1156)$, and Web of Science $(n=318)$.

Duplicate records ( $n=419)$ were removed, leaving 1695 records for title/abstract screening; 84 articles were retrieved for full text screening. From those, 64 records were excluded. Reasons for exclusion were: language other than English $(n=22)$, studies using transcranial stimulation $(n=18)$, reviews $(n=7)$, abstract only was available $(n=6)$, methods did not state the site of stimulation/electrode placement $(n=2)$, no measure of tinnitus included $(n=2)$, intracochlear stimulation $(n=2)$, conference workshop report $(n=2)$, electromagnetic nerve stimulation $(n=1)$, vagal nerve stimulation $(n=1)$, and hand stimulation $(n=1)$. This left 20 articles for data extraction. No additional records were identified from manual searches of reference lists in included articles.
Of 20 publications that met our inclusion criteria, the majority $(n=13)$ were uncontrolled before-and-after studies $[15,17,19-29], 3$ were controlled before-and-after studies [30-32], 2 were a series of case studies [16,33], 1 was a prospective cohort study [34], and 1 was a quasi-randomised placebo controlled trial [35].

Of the 20 identified studies, 14 used invasive methods for electrical ear stimulation [15-17,19,20,22-24,26-29,33,34] and 6 used non-invasive methods [21,25,30-32,35]

\section{Invasive ear stimulation}

Characteristics of the invasive studies, including stimulation parameters and main efficacy data, are included in Table 2.

Among the 14 studies, 12 used equipment that was specifically designed for transtympanic electrical ear stimulation $[15-17,19,20,22,23,26-28,33,34]$ and 2 studies provided stimulation via a cochlear implant system using round window or extracochlear electrode [24,29]. One study included both: participants with cochlear implants (electrode inserted into the cochlea) and participants receiving transtympanic electrical stimulation [29]. For that study, only data from participants receiving transtympanic stimulation were analysed for this review.

A majority $(n=8)$ of the studies investigated the effects of stimulation to the promontory $[16,17,22,23,26-28,34]$, while 3 studies investigated the effects of both promontory and round window stimulation $[15,19,33]$ and 3 studies investigated the effects of round window stimulation $[20,24,29]$.

There were 5 studies which investigated the effects of direct current $[19,20,22,33,34], 8$ investigated the effects of alternating current $[16,17,23,24,26-29]$, and 1 study investigated the effect of both direct and alternating currents [15]. Of the studies that investigated the effects of direct current, 4 used current with a positive polarity and 2 used both positive and negative polarity. A wide range of current intensities was used in the different studies, ranging from $1 \mu \mathrm{A}$ to $1 \mathrm{~mA}$. The frequency of the current used varied between $50 \mathrm{~Hz}$ and $10 \mathrm{kHz}$.

There were 10 studies which used only a single session for tinnitus suppression [15,17,19,20,22,23,28,29,33,34]. Di Nardo et al. [22] and Konopka et al. [34] reported a single session of 1 minute duration. Watanabe et al. [28] reported a single session: 10 seconds in 15 patients, $30 \mathrm{sec}-$ onds in 24 patients, and 60 seconds in 17 patients. Perez et al. [27] reported 3 consecutive 30-minute sessions every other day. Matsushima et al. [16] reported individual differences in duration of stimulation: Case 1, 30 mins, twice per day; Case 2, around 1 hour up to 4 times a day; Case 3, twice a day; Case 4, 60 min twice per day.

Efficacy of invasive ear stimulation: Success rates of electrical stimulation varied, between $22 \%$ [23] and $86 \%$ of patients $[19,34]$ reporting improvement in tinnitus. Notably, the definition of improvement differed between the studies. In the majority, improvement meant suppression of tinnitus (i.e. reduction in loudness, including disappearance of tinnitus). However, Konopka et 


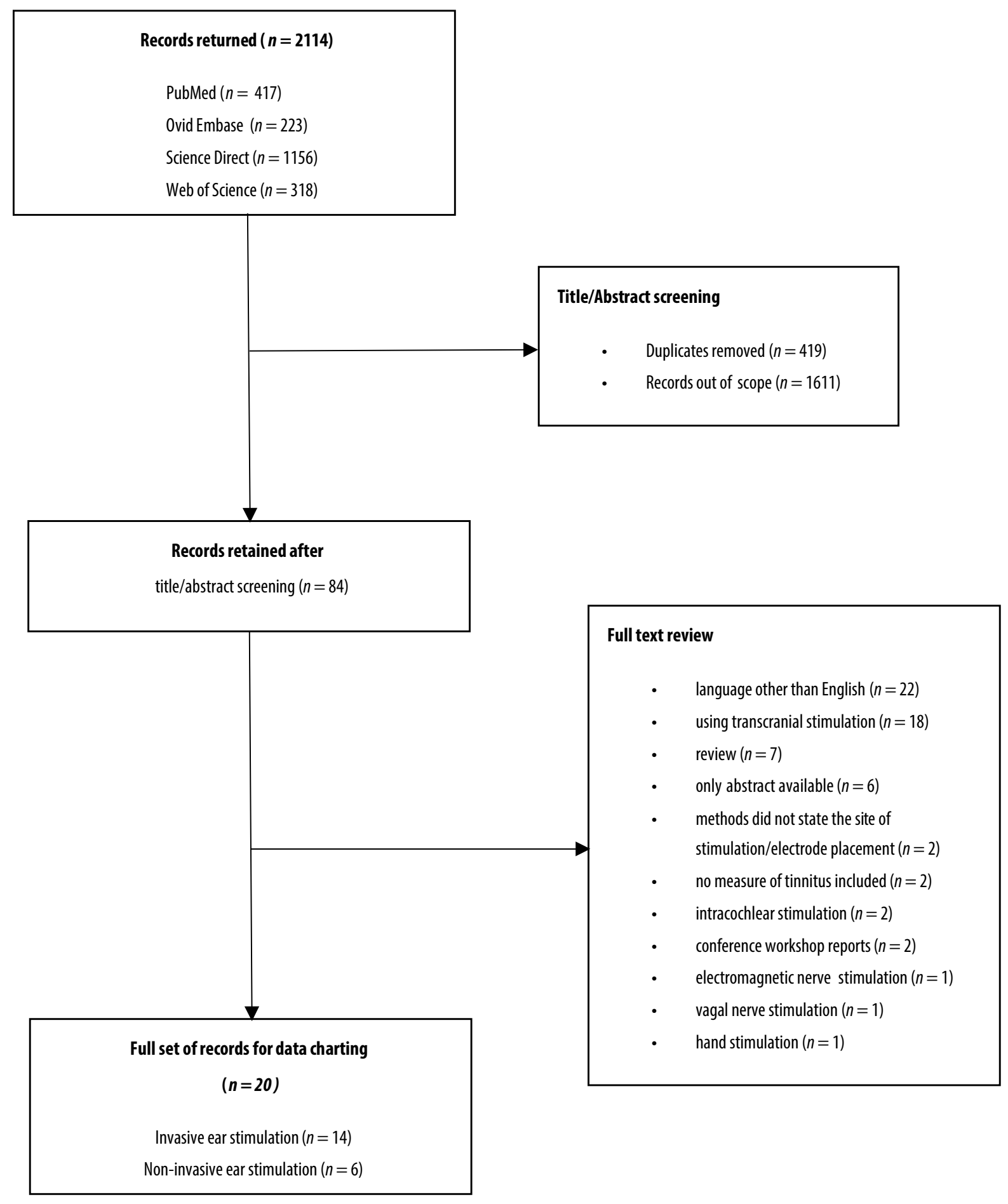

Figure 1. Flow diagram illustrating search strategy and scoping review stages

al. [34] also included 'improved frequency characteristics' as well as disappearance or attenuation of tinnitus as an improvement in tinnitus. Suppression of tinnitus was assessed and classified in different ways in different studies. A majority of studies relied on patient report. Perez et al. [27] used a 10-point visual analogue scale (VAS) to assess tinnitus loudness before and after the intervention, and used a criterion of reduction in score by 2 levels or more in order to classify it as an improvement. In that study VAS scores were collected at multiple time points between 24 hours and 4 weeks after treatment, and meeting the above criterion at any time point was reported as an improvement. Only two studies used a validated questionnaire - the Tinnitus Handicap Inventory (THI) - to measure improvement in tinnitus [22,27]. Di Nardo et al. [22] reported a reduction in THI scores 
Table 2. Characteristics of invasive studies including stimulation parameters and main efficacy data

\begin{tabular}{|c|c|c|c|c|c|c|}
\hline Study & Study design & $\begin{array}{l}\text { No of } \\
\text { participants } \\
\text { with tinnitus }\end{array}$ & $\begin{array}{c}\text { Site of } \\
\text { stimulation }\end{array}$ & $\begin{array}{l}\text { Type of } \\
\text { current }\end{array}$ & Current intensity & Current frequency \\
\hline Aran, 1981 & Case studies & 39 & $\begin{array}{l}\text { Promon- } \\
\text { tory and/ } \\
\text { or round } \\
\text { window }\end{array}$ & $\begin{array}{l}\text { DC: positive } \\
\text { polarity }\end{array}$ & $20-500 \mu \mathrm{A}$ & $50-1600 \mathrm{~Hz}$ \\
\hline $\begin{array}{l}\text { Aran \& } \\
\text { Cazals, } 1981\end{array}$ & $\begin{array}{l}\text { Uncontrolled } \\
\text { before and } \\
\text { after }\end{array}$ & 84 & $\begin{array}{l}\text { Promontory } \\
\text { and round } \\
\text { window }\end{array}$ & $\begin{array}{c}\text { AC and DC } \\
\text { DC positive } \\
\text { and negati- } \\
\text { ve polarity. } \\
\text { Square } \\
\text { waves }\end{array}$ & $\begin{array}{c}1 \mu \mathrm{A}-30 \mathrm{~mA} \\
\text { (equipment range) }\end{array}$ & $50-6400 \mathrm{~Hz}$ \\
\hline
\end{tabular}

\begin{tabular}{|c|c|c|c|c|c|c|}
\hline $\begin{array}{l}\text { Cazals et al., } \\
1978\end{array}$ & $\begin{array}{l}\text { Uncontrolled } \\
\text { before and } \\
\text { after }\end{array}$ & 7 & $\begin{array}{l}\text { Promontory } \\
\text { and round } \\
\text { window }\end{array}$ & $\begin{array}{l}\text { DC: positive } \\
\text { and negati- } \\
\text { ve polarity. } \\
\text { Rectangular } \\
\text { pulses }\end{array}$ & $\begin{array}{c}1 \mu \mathrm{A} \text { to } 30 \mathrm{~mA} \\
\text { (equipment range); } \\
\text { intensity was raised } \\
\text { progressively }\end{array}$ & $\begin{array}{l}\text { The stimulation frequencies } \\
\text { were chosen at octave intervals; } \\
\text { one participant was stimulated } \\
\text { with the constant current with } \\
\text { constant intensity }\end{array}$ \\
\hline $\begin{array}{l}\text { Cazals et al., } \\
1984\end{array}$ & Case study & 1 & $\begin{array}{l}\text { Round } \\
\text { window }\end{array}$ & $\begin{array}{l}\text { DC: positive } \\
\text { polarity, sine } \\
\text { wave }\end{array}$ & $\begin{array}{l}\text { Up to } 3 \mathrm{~V} \\
\text { increased to } 5 \mathrm{~V} \\
\text { after } 2 \text { months } \\
\text { (adjustable) }\end{array}$ & Cut off frequency of $1000 \mathrm{~Hz}$ \\
\hline
\end{tabular}

\begin{tabular}{|c|c|c|c|c|c|}
\hline $\begin{array}{l}\text { Di Nardo } \\
\text { et al., } 2009\end{array}$ & $\begin{array}{l}\text { Uncontrolled } \\
\text { before and } \\
\text { after }\end{array}$ & 11 & Promontory & $\begin{array}{l}\text { DC: positive } \\
\text { polarity }\end{array}$ & $\begin{array}{c}\text { 0-500 } \mu \mathrm{A} \text {. Started with } \\
\text { lowest and increased } \\
\text { until patient reported } \\
\text { discomfort }\end{array}$ \\
\hline
\end{tabular}

$50,100,200,400,800$, and $1600 \mathrm{~Hz}$. Started with lowest pulse rate and increased until patient reported discomfort

\begin{tabular}{|c|c|c|c|c|c|c|}
\hline $\begin{array}{l}\text { Graham \& } \\
\text { Hazell, } 1977\end{array}$ & $\begin{array}{l}\text { Series of case } \\
\text { studies }\end{array}$ & 9 & Promontory & $A C$ & $\begin{array}{l}\text { Max } 100 \mu \mathrm{A} \text {, increased } \\
\text { until one of three things } \\
\text { happened: } \\
\text { the patient heard } \\
\text { a sound, tinnitus } \\
\text { was suppressed, } \\
\text { vertigo or a somatic } \\
\text { sensation was felt }\end{array}$ & Began with $100 \mathrm{~Hz}$ \\
\hline $\begin{array}{l}\text { Hazell et al., } \\
1993\end{array}$ & $\begin{array}{l}\text { Uncontrolled } \\
\text { before and } \\
\text { after }\end{array}$ & 9 & $\begin{array}{l}\text { Round } \\
\text { window }\end{array}$ & $\begin{array}{l}\text { AC-sinusoi- } \\
\text { dal current }\end{array}$ & $\begin{array}{c}\text { Maximum current } \\
\text { intensity was } 300 \mu \mathrm{A}\end{array}$ & $20-200 \mathrm{~Hz}$ \\
\hline $\begin{array}{l}\text { Konopka } \\
\text { et al., } 2001\end{array}$ & $\begin{array}{l}\text { Prospective } \\
\text { cohort study }\end{array}$ & $\begin{array}{l}111 \text { (43 with } \\
\text { noise-in- } \\
\text { duced and } \\
68 \text { with non- } \\
\text {-noise-indu- } \\
\text { ced hearing } \\
\text { loss) }\end{array}$ & Promontory & $\begin{array}{l}\text { DC: positive } \\
\text { polarity }\end{array}$ & $\begin{array}{c}20-600 \mu \mathrm{A} \text { (depen- } \\
\text { ding on the individual } \\
\text { tolerance) }\end{array}$ & $0.06-10 \mathrm{kHz}$ \\
\hline
\end{tabular}


Duration of treatment

Adverse effects
Efficacy
Not reported
Vertigo in 5 patients (with both positive and negative

One session, suppression during stimulation was investigated stimulation for 1 patient, and with negative stimulation for 4 patients)
One session, suppression during stimulation was investigated investigated suppression during stimulation

Round window stimulation was more practical (lower current needed) for suppressing tinnitus with positive pulses. Suppression of tinnitus was only achieved with ipsilateral stimulation. Only positive current was effective for tinnitus suppression. Negative current elicited auditory sensation. Frequencies efficient for tinnitus suppression varied from 50 to $1600 \mathrm{~Hz}$. Current intensity effective for suppression of tinnitus varied from 15 to $500 \mu \mathrm{A}$

Tinnitus suppression only occurred during stimulation of the ipsilateral ear. Suppression was only achieved with positive currents. Suppression of tinnitus during round window stimulation was Discomfort at certain frequ- observed in $60 \%$ of patients and was always total. During promonencies tory stimulation reduction in tinnitus was observed in $43 \%$ of patients but was total only in $25 \%$ of patients. The intensities of currents needed for tinnitus suppression varied across patients and ranged from 5 to $300 \mu \mathrm{A}$

DC of negative polarity did not suppress tinnitus and produced auditory sensations. DC of positive polarity suppressed tinnitus in 6 out of 7 participants. The site of stimulation of the cochlea (promontory or round window) was not obviously related to the intensity of the pulses necessary to suppress tinnitus. The intensities of currents needed for suppression of tinnitus varied from 20 to $300 \mu \mathrm{A}$. Frequencies effective for suppression of tinnitus varied between patients and ranged from $>50$ to $>200 \mathrm{~Hz}$. Suppression occurred only during stimulation
Unpleasant effect in patient's head when maximum intensity was increased to $5 \mathrm{~V}$
A voltage of $2 \mathrm{~V}$ started to diminish participant's tinnitus and $5 \mathrm{~V}$ was necessary to suppress it totally. Some tinnitus relief was reported by the patient when the stimulator was on
Chronic stimulation, use at will
Five patients (45.4\%) reported complete suppression of tinnitus, $4(36.4 \%)$ reported tinnitus attenuation, and 2 (18.2\%) said it was unchanged immediately after stimulation. After 1 month post stimulation 5 patients reported that their tinnitus intensity was much lower than before the treatment, while 6 reported no change or their tinnitus loudness returned to pre-stimulation levels. No one
At least 60 seconds of stimulathe best tinnitus suppression
Discomfort at higher stimulation intensities - ranging from 69 to $900 \mu \mathrm{A}$ and depending on pulse rate reported tinnitus worsening. Overall, 9 of the 11 patients (82\%) had immediate tinnitus benefit from the stimulation. Most effective

frequencies for tinnitus suppression or reduction were 50 and $100 \mathrm{~Hz}$. Current intensities effective for tinnitus suppression ranged from tion at the frequency that caused 60 to $440 \mu \mathrm{A}$. Three patients reported tinnitus attenuation with subthreshold stimulation (i.e. not eliciting sound). The THI scores

1 month after stimulation were reduced in 5 patients (reduction from 16 to 52 points) and remained unchanged in 6 patients (reduction from 0 to 2 points)

In 2 of 9 patients (22\%) tinnitus was suppressed by stimulation. In the first case effective stimulation parameters were
Pressure in the ear ( 4 patients), numbness, vibra-

1 session tion, or tingling in the throat or cheek (6), pain in the ear

(3), tickling in the ear (1)
$30 \mathrm{~Hz}$ and $80 \mu \mathrm{A}$; tinnitus returned soon after stimulation. In the second case effective stimulation parameters were $10 \mathrm{~Hz}$ and $20 \mu \mathrm{A}$, applied for $30 \mathrm{~s}$. The suppression lasted $4 \mathrm{~h}$. In one patient tinnitus increased with stimulation at $100 \mathrm{~Hz}$ and $5 \mu \mathrm{A}$.

In 9 out of 13 participants (with and without tinnitus) the sensation of sound was evoked by the stimulation

In 7/9 patients (78\%), total suppression of tinnitus was obtained by a sinusoidal current above hearing threshold and below subthreshold stimulation. In 2 patients, no tinnitus suppression was obtained at any tested frequency.

The frequencies most effective for tinnitus suppression were 20 and $50 \mathrm{~Hz}$.

Tinnitus was suppressed during stimulation in all patients. After stimulation, 96 patients (86\%) reported tinnitus suppression which was maintained from several hours to 1 week. After 90 days tinnitus was improved in $42 \%$ of patients with noise-induced hearing loss and $50 \%$ of patients with non-noise-induced hearing loss. Improvements included disappearance of tinnitus, improved tinnitus frequency characteristics, and reduced tinnitus loudness.
2/111 patients noted deterioration in their tinnitus;

$1 / 111$ patient claimed loudness had increased after electrostimulation ters of electrical impulses were individually different and

depended on tinnitus parameters and patient's sensation. auditory discomfort. Tinnitus suppression was not observed for Analysis of tinnitus suppression as a function of current intensity and frequency showed that better results were obtained by using frequencies below $1 \mathrm{kHz}$ (but not statistically significant) 


\begin{tabular}{|c|c|c|c|c|c|c|}
\hline Study & Study design & $\begin{array}{l}\text { No of } \\
\text { participants } \\
\text { with tinnitus }\end{array}$ & $\begin{array}{l}\text { Site of } \\
\text { stimulation }\end{array}$ & $\begin{array}{l}\text { Type of } \\
\text { current }\end{array}$ & Current intensity & Current frequency \\
\hline $\begin{array}{l}\text { Matsushi- } \\
\text { ma et al., } \\
1994\end{array}$ & $\begin{array}{l}\text { Uncontrolled } \\
\text { before and } \\
\text { after }\end{array}$ & $\begin{array}{l}112 \text { (129 tin- } \\
\text { nitus ears) }\end{array}$ & Promontory & $\begin{array}{l}\text { AC: sinusoi- } \\
\text { dal waves }\end{array}$ & 0 to70 $\mu \mathrm{A}$ & $\begin{array}{c}10 \mathrm{kHz} \text { modulated at } 1 \mathrm{kHz} \\
\text { in the form of charge-balanced } \\
\text { sinusoidal waves }\end{array}$ \\
\hline
\end{tabular}

\begin{tabular}{|c|c|c|c|c|c|c|}
\hline $\begin{array}{l}\text { Matsushima } \\
\text { et al., } 1996\end{array}$ & Case studies & 4 & Promontory & $\begin{array}{l}\text { AC: sinuso- } \\
\text { idal wave }\end{array}$ & $\begin{array}{c}\text { Maximum stimulus } \\
\text { intensity: } \\
\text { Case 1, } 70 \mu \mathrm{A} \\
\text { Case } 2,200 \mu \mathrm{A} \\
\text { Case } 3,300 \mu \mathrm{A} \\
\text { Case } 4,100 \mu \mathrm{A}\end{array}$ & $\begin{array}{l}10 \mathrm{kHz} \text { sinusoidal wave } \\
\text { modulated at } 100 \mathrm{~Hz}\end{array}$ \\
\hline
\end{tabular}

\begin{tabular}{|c|c|c|c|c|c|}
\hline $\begin{array}{l}\text { Okusa et al., } \\
1993\end{array}$ & $\begin{array}{l}\text { Uncontrolled } \\
\text { before and } \\
\text { after }\end{array}$ & $\begin{array}{l}65 \text { (68 ears } \\
\text { with tinni- } \\
\text { tus) }\end{array}$ & Promontory & $A C$ & $\begin{array}{l}\text { The maximum intensity } \\
\text { was limited to less than } \\
100 \mu \mathrm{A} \text { in order to avoid }\end{array}$ \\
\hline
\end{tabular}

Four frequencies of electric pulses were applied: 50, 100 200, and $400 \mathrm{~Hz}$

$\begin{array}{ccccc}\begin{array}{l}\text { Perez et al., Uncontrolled } \\ \text { before and } \\ \text { after }\end{array} & 10 \quad \text { Promontory } & \begin{array}{c}\text { AC: rectan- } \\ \text { gular pulses (equipment ran }\end{array} & \begin{array}{c}\text { ge, optimal stimulation } \\ \text { level was set 20-30\% } \\ \text { lower than the discom- } \\ \text { fort level) }\end{array}\end{array}$

$100 \mathrm{~Hz}$ and $1800 \mathrm{~Hz}$ fort level)

\begin{tabular}{|c|c|c|c|c|c|}
\hline $\begin{array}{l}\text { Rubinstein } \\
\text { et al., } 2003\end{array}$ & $\begin{array}{l}\text { Uncontrolled } \\
\text { before and } \\
\text { after }\end{array}$ & 11 & $\begin{array}{l}\text { Round } \\
\text { window }\end{array}$ & $A C$ & $\begin{array}{c}\text { Maximum to avoid pain, } \\
\text { typically } 300-400 \mu \mathrm{A} \text {. } \\
\text { Maximum current was } \\
1.1 \mathrm{~mA}\end{array}$ \\
\hline $\begin{array}{l}\text { Watanabe } \\
\text { et al., } 1997\end{array}$ & $\begin{array}{l}\text { Uncontrolled } \\
\text { before and } \\
\text { after }\end{array}$ & 56 & Promontory & $\begin{array}{c}A C: \text { square } \\
\text { waves }\end{array}$ & $\begin{array}{l}\text { Mean intensity of the } \\
\text { electric stimulus was } \\
38 \mu \mathrm{A} \text { (SD 26), and ran- } \\
\text { ged from } 5 \text { to } 160 \mu \mathrm{A}\end{array}$ \\
\hline
\end{tabular}

$4800 \mathrm{~Hz}(4800 \mathrm{pps})$, pulse durations were 25,50 , or $80 \mu \mathrm{s}$
( 1 month after stimulation) in 5 of 11 patients (reduction from 16 to 52 points), while the scores remained unchanged in 6 of 11 patients (reduction from 0 to 2 points). No statistical analysis was performed on those scores. Perez et al. [27] reported that THI scores to be significantly lower 4 weeks after treatment (reduction from 65.2 (SD 16.6) to 50.2 (SD 18.7), $p=0.0039$ ).

Type of current: Reduction of tinnitus was reported only when positive direct current stimulation was used (or alternating current). Negative currents usually elicited auditory sensations and did not result in improvement of tinnitus $[15,19,33]$. Aran [33] concluded that round window stimulation was more practical since a lower current intensity was required for suppressing tinnitus than with promontory stimulation. Aran and Cazals [15] reported more participants experienced tinnitus suppression (60\%) when the round window was stimulated with direct positive current in comparison with $43 \%$ when stimulation was applied to the promontory. They also reported that suppression with round window stimulation was always total, while total suppression was achieved in only $25 \%$ of the participants with promontory stimulation. In another study, Cazals et al. [19] concluded that the site of stimulation of the cochlea (promontory or round window) was not obviously related to the intensity of the pulses necessary to suppress the tinnitus. There did not seem to be an obvious pattern of success rates associated with the stimulation site (promontory vs round window) in the remaining studies.

Laterality of stimulation: Two studies specifically reported that tinnitus suppression occurred only when ipsilateral 
Stimulation was performed up to 3 times a week at 3-week intervals on the ipsilateral ear. Stimulation was maintained for $60 \mathrm{~s}$ at $70 \mu \mathrm{A}$

Not reported

Electrical promontory stimulation relieved tinni-
tus in $74(57.4 \%)$ of 129 ears ( 112 patients). There was no significant difference in etiology of tinnitus, age, average audiogram, or tinnitus frequency between patients who responded to electrical stimulation and those who did not. Most patients who did not respond to the initial stimulation trial did not respond to subsequent trials, suggesting that the initial response to treatment predicts the subsequent response

Patients were able to use the stimulation at home whenever they needed treatment. Case 1 , 30 min, twice per day

Case 2, around 1 hour up to 4 times a day Case 3, twice a day

Case 4, 60 min twice per day
Perforated ear drum in case 4, healed within 1 month
All patients reported improvement in sleep and tinnitus after the stimulation. 2 patients did not experience tinnitus throughout the day after the stimulation, and in 2 tinnitus was weaker after the stimulation.

The effect on tinnitus suppression were not stable in all cases. When patients got cold or tired, tinnitus often worsened. Hearing sensation was not perceived during electrical stimulation
Single session, bursts of biphasic used, each lasting $500 \mathrm{~ms}$ pulses of $0.1 \mathrm{~ms}$ duration were
Side-effects of the stimulation occurred in 17 patients.
7 patients reported dizziness,
5 discomfort of the throat,
3 discomfort of the nose,
1 facial spasms, and 1 a feel-
ing of numbness in the face. These side-effects dis- appeared soon after cessation of stimulation.
Perforation of the tympanic membrane was not seen in any case

Reduction in tinnitus loudness was reported in 46 out of 68 ears $(67.6 \%)$. Stimulation was most effective in cases of noise-induced hearing loss (100\%; 3/3), followed by idiopathic sudden deafness $(88 \% ; 14 / 16)$, Meniere's disease $(83 \% ; 5 / 6)$, labyrinthitis $(75 \% ; 6 / 8)$, ototoxicity $(67 \% ; 4 / 6)$, and unknown origin $(76 \% ; 13 / 17)$. The treatment had no effect on patients with acoustic neuroma except for one (8\%; 1/12). An electric pulse of $50 \mathrm{~Hz}$ was the most effective followed by one of $100 \mathrm{~Hz}$

Maximum decrease in tinnitus loudness as measured with visual analog scale of 2 levels or more was observed in 5 out of 10 patients (50\%) at one of the time points between $24 \mathrm{~h}$ and 4 weeks after treatment. Loudness scores returned to baseline level

Three consecutive sessions were conducted every other day. Total duration of each session was 30 min: 15 min at $100 \mathrm{~Hz}$ and None observed $15 \mathrm{~min}$ at $1800 \mathrm{~Hz}$

4 weeks after treatment. THI score was significantly lower at 4 weeks post-treatment (reduction from 65.2 \pm 16.6 to $50.2 \pm 18.7$, $p=0.0039)$.

Tinnitus pitch, minimum masking levels, and matched tinnitus loudness did not differ significantly before and after treatment

$5 / 11(45 \%)$ patients reported significant or complete tinnitus suppression with either no perception or only a transient perception of the stimulus. 3 patients (28\%) perceived tinnitus sup-

1 testing session, lasting $2-3 \mathrm{~h}$

Pain evoked by stimulation above 300-400 $\mathrm{AA}$

\begin{abstract}
pression only in association with the perception of the stimulus. 3 patients ( $28 \%$ ) reported no effects on tinnitus
\end{abstract}

Developed in 6 patients.

discomfort of the pharynx (3), discomfort of the nose

(1), discomfort of the

oral cavity (1), cough (1), discomfort of the lips and oral cavity (1)
29 patients $(52 \%)$ said their tinnitus was suppressed after stimulation. Tinnitus became inaudible in 2 cases and temporarily worse in 1 patient. The duration of post-stimulus suppression varied from less than $1 \mathrm{~h}$ to over a month. There were no significant effect of stimulus duration on tinnitus suppression stimulation was applied and was not effective for contralateral or central tinnitus $[15,33]$.

Intensity of current: The intensities of current that were most effective for tinnitus varied between studies and between individual patients and ranged from 5 to $500 \mu \mathrm{A}$. Perez et al. [27] reported that the optimal stimulation level was one set about $20-30 \%$ lower than the discomfort level. Konopka et al. [34] performed an analysis of tinnitus suppression as a function of current intensity and did not find a statistically significant relationship.

Frequency of stimulation: Different studies tested stimulation frequencies ranging from $10 \mathrm{~Hz}$ to $10 \mathrm{kHz}$. The frequency of the current which was the most effective for tinnitus suppression varied between studies and ranged from 10 to $1600 \mathrm{~Hz}$. While Aran [33] found the whole range of frequencies between 50 and $1600 \mathrm{~Hz}$ effective for different participants, most studies found lower frequencies more effective than higher frequencies. The most effective frequencies found by different studies were $50-200 \mathrm{~Hz}$ [19], 50-100 Hz [22], 10 and $30 \mathrm{~Hz}$ [23], 20 and $50 \mathrm{~Hz}$ [24], and $50 \mathrm{~Hz}$ [17]. Konopka et al. [34] analysed tinnitus suppression as a function of current frequency and showed that better results were obtained by using frequencies below $1 \mathrm{kHz}$, but this result was not statistically significant.

Duration of tinnitus suppression: The reported duration of tinnitus suppression ranged from suppression reported only during the ear stimulation to lasting for over a month. Five studies described tinnitus suppression occurring during or immediately after the stimulation $[15,19,20,24,33]$. In the study by Graham and Hazell [23], for one of the participants in which stimulation 
Table 3. Characteristics of non-invasive studies including stimulation parameters and main efficacy data

\begin{tabular}{|c|c|c|c|c|c|c|}
\hline Study & Study design & $\begin{array}{l}\text { No of } \\
\text { participants } \\
\text { with tinnitus }\end{array}$ & $\begin{array}{c}\text { Active electrode } \\
\text { placement }\end{array}$ & $\begin{array}{l}\text { Type of } \\
\text { current }\end{array}$ & Current intensity & Current frequency \\
\hline $\begin{array}{l}\text { Daneshi et al., } \\
2005\end{array}$ & $\begin{array}{l}\text { Uncontrolled } \\
\text { before and after } \\
\text { study }\end{array}$ & 52 & $\begin{array}{l}\text { Surface tympa- } \\
\text { nic membrane } \\
\text { electrode inserted } \\
\text { through external } \\
\text { ear canal }\end{array}$ & $\begin{array}{l}\text { AC (square } \\
\text { waves) }\end{array}$ & 60 to $500 \mu \mathrm{A}$ & $600 \mathrm{~Hz}$ \\
\hline Kuk et al., 1989 & $\begin{array}{c}\text { Uncontrolled } \\
\text { before and after } \\
\text { study }\end{array}$ & 10 & Eardrum & $\begin{array}{c}\text { AC (sine, } \\
\text { triangular, } \\
\text { and square } \\
\text { waves) }\end{array}$ & $2 \mathrm{~mA}$ (maximum) & $62-800 \mathrm{~Hz}$ \\
\hline $\begin{array}{l}\text { Mielczarek et al., } \\
2013\end{array}$ & $\begin{array}{c}\text { Controlled } \\
\text { before and after } \\
\text { study }\end{array}$ & 80 & $\begin{array}{l}\text { Immersed in the } \\
\text { external ear canal } \\
\text { filled with } 0.9 \% \text { sa- } \\
\text { line solution, avo- } \\
\text { iding contact with } \\
\text { the skin of the } \\
\text { canal }\end{array}$ & $\begin{array}{l}\mathrm{DC} \text { (positive } \\
\text { polarity) }\end{array}$ & $\begin{array}{c}\text { Ranged from } \\
0.15 \text { to } 1.15 \mathrm{~mA} \text {. } \\
\text { Stimulation star- } \\
\text { ted at maximum } \\
\text { current intensity and } \\
\text { continued if well } \\
\text { tolerated or redu- } \\
\text { ced if pain or unple- } \\
\text { asant sensation was } \\
\text { reported }\end{array}$ & $\begin{array}{l}\text { Ranged from } \\
250 \text { to } 8000 \mathrm{~Hz} \text { and } \\
\text { was chosen for each } \\
\text { patient to match their } \\
\text { tinnitus frequency }\end{array}$ \\
\hline $\begin{array}{l}\text { Mielczarek et al., } \\
2014\end{array}$ & $\begin{array}{l}\text { A double-blind } \\
\text { quasi- } \\
\text { randomized pla- } \\
\text { cebo controlled } \\
\text { trial }\end{array}$ & 120 & $\begin{array}{l}\text { Immersed in the } \\
\text { external ear canal } \\
\text { filled with } 0.9 \% \text { sa- } \\
\text { line solution, avoi- } \\
\text { ding contact with } \\
\text { the skin of the } \\
\text { canal }\end{array}$ & $\begin{array}{l}\text { DC (positive } \\
\text { polarity) }\end{array}$ & $\begin{array}{c}\text { Ranged from } \\
0.15 \text { to } 1.15 \mathrm{~mA} \text {. } \\
\text { Stimulation star- } \\
\text { ted at maximum } \\
\text { current intensity and } \\
\text { continued if well } \\
\text { tolerated or redu- } \\
\text { ced if pain or unple- } \\
\text { asant sensation was } \\
\text { reported }\end{array}$ & $\begin{array}{c}\text { Ranged from } \\
250 \text { to } 8000 \mathrm{~Hz} \text { and } \\
\text { was chosen for each } \\
\text { patient to match their } \\
\text { tinnitus frequency }\end{array}$ \\
\hline $\begin{array}{l}\text { Mielczarek et al., } \\
2016\end{array}$ & $\begin{array}{l}\text { Controlled } \\
\text { before and after } \\
\text { pilot study }\end{array}$ & 12 & $\begin{array}{l}\text { Immersed in the } \\
\text { external ear canal } \\
\text { filled with } 0.9 \% \text { sa- } \\
\text { line solution, avo- } \\
\text { iding contact with } \\
\text { the skin of the } \\
\text { canal }\end{array}$ & $\begin{array}{l}\text { DC (negative } \\
\text { polarity) }\end{array}$ & $0.14-1.08 \mathrm{~mA}$ & $250 \mathrm{~Hz}$ \\
\hline $\begin{array}{l}\text { Mielczarek et al., } \\
2018\end{array}$ & $\begin{array}{c}\text { Controlled } \\
\text { before and after } \\
\text { study }\end{array}$ & 49 & $\begin{array}{l}\text { Immersed in the } \\
\text { external ear canal } \\
\text { filled with } 0.9 \% \text { sa- } \\
\text { line solution, avo- } \\
\text { iding contact with } \\
\text { the skin of the } \\
\text { canal }\end{array}$ & $\begin{array}{l}\text { DC (positive } \\
\text { and negati- } \\
\text { ve polarity) }\end{array}$ & $\begin{array}{l}\text { Amplitude ran- } \\
\text { ge of } 0.01-2.24 \mathrm{~mA} \text {, } \\
\text { started with maxi- } \\
\text { mum well-tolerated } \\
\text { current intensity }\end{array}$ & $\begin{array}{c}0.25,1,2,3,4,5,6,7 \\
8 \mathrm{kHz}\end{array}$ \\
\hline
\end{tabular}

was effective, tinnitus returned soon after stimulation and for another the suppression lasted for 4 hours after the stimulation. Okusa et al. [17] reported tinnitus suppression lasting from a few minutes to more than 3 days in different participants. Rubinstein et al. [29] reported the duration of tinnitus suppression in some patients lasting from 45 minutes to 72 hours after stimulation. Di Nardo et al. [22] reported that for some patients reduction in tinnitus loudness and reduction in THI score was still present 1 month after the stimulation. Konop$\mathrm{ka}$ et al. [34] reported tinnitus suppression in all participants during stimulation, for $86 \%$ of participants tinnitus suppression was maintained for several hours to 1 week, and in $42 \%$ positive effects on tinnitus were still present 90 days after stimulation. Watanabe et al. [28] reported that post-stimulus suppression lasted from less than 1 hour to over a month.

In the study by Perez et al. [27], the loudness of tinnitus as measured by VAS returned to baseline levels 4 weeks after stimulation; however, the reduction in THI score was statistically significant 4 weeks post stimulation.

Adverse effects: Three studies did not observe any pain or unpleasant sensation during or after electrical stimulation $[19,26,27]$. The other 10 studies reported different levels of adverse effects: pressure, pain, and tickling sensations in the ear; unpleasant sensations in the head; deterioration of tinnitus and increase in tinnitus loudness; dizziness; and discomfort in the pharynx, oral cavity, and nose. Aran [33] reported that with higher current intensities an 
Duration of treatment

Adverse effects

Efficacy
7 sessions of $30 \mathrm{~min}$

Not reported

There was significant reduction of TQ scores from 50.7 (SD 19.3) to 39.0 (SD 20.4), $p=0.001$ (paired $t$-test) 20 of 32 patients $(62.5 \%)$ indicated their tinnitus was suppressed after ES. There was no significant change in tinnitus pitch in patients who experienced tinnitus suppression nor in those whose tinnitus was not suppressed ( $t$-test, $p>0.05$ )

$5 / 10$ patients who reported change in tinnitus went on to the treatment phase after screening. Those patients then reported decre-

Feelings of 'pressure', 'warmth', 'blockage', and 'tingles' during the screening phase ase in annoyance (33-100\%) and loudness (36-100\%) of tinnitus after treatment. Effects lasted $40 \mathrm{~s}$ to $4 \mathrm{~h}$. Triangular and square wave stimuli were more effective than sine waves. Optimal current level ranged from 4 to $900 \mu \mathrm{A}$ depending on stimulus frequency. Stimulus frequencies showing an effect ranged from 62 to $8000 \mathrm{~Hz}$

Total of 15 sessions. Each stimulation session lasted $4 \mathrm{~min}$
Pain or unpleasant sensation at maximum current intensity in some patients $(1.15 \mathrm{~mA})$

The modified THI scores were reduced in 25 ears in the ear stimulation only group (43.1\%) and in 20 ears in the ear stimulation with kinesitherapy group (32.8\%). Further reduction of modified THI scores was observed in both groups 30 days after treatment ( 56.9 and $45.9 \%$ respectively, $p<0.05$ )

After treatment, the number of ears with permanent tinnitus decreased in both groups

15 sessions of 4 min applied No harmful effects on the 3-4 times a week hearing organ were observed.

Pain or unpleasant sensation at maximum current intensity in some patients $(1.15 \mathrm{~mA})$
The modified THI scores were reduced directly after treatment; intervention group showed improvement in 45 ears (37.8\%) and placebo group in 20 ears (30.8\%).

There was a significant decrease in the number of ears with tinnitus directly after ES (from 119 to 79, disappearance of tinnitus in 40 ears) and placebo stimulation (from 65 to 61, disappearance of tinnitus in 4 ears; $p<0.05$ ). Decrease in the number of ears with tinnitus was significant at 30 and 90 days after stimulation in the intervention group $(p<0.05)$ but not significant in the placebo group $(p>0.05)$

In group with unilateral tinnitus, improvement (reduction in loudness measured with VAS) was observed in $5 / 6$ ears $(83.3 \% ; p=0.013)$. Tinnitus disappeared in $2 / 6$ ears (33.3\%).

In group with bilateral tinnitus, reduction in loudness measured with VAS was observed in $7 / 12$ ears $(58.3 \% ; p=0.006)$; tinnitus disappeared in $2 / 12$ ears. There was no significant difference between the two groups in terms of reduction of tinnitus loudness measured with VAS $(p=0.699)$

Reduction of tinnitus loudness measured with VAS was observed in $75 \%$ of stimulated ears. The reduction, from 5.5 (SD 1.7) to 3.3 (SD 2.4) after stimulation, was statistically significant $(p<0.001)$.

Directly after electrical stimulation, there was improvement in 21 ears
$(75 \%)$, no change in 5 ears (18\%), and worsening in 2 ears
$(7 \%)$. In 10 ears, (22\%) tinnitus disappeared

$(75 \%)$, no change in 5 ears (18\%), and worsening in 2 ears
$(7 \%)$. In 10 ears, (22\%) tinnitus disappeared
One session of multiple stimulation periods with different parameters

\section{porary pain was repor-} ted by people in both groups: $25(51 \%)$ in the tinnitus group and $14(41 \%)$ in the healthy subjects group. In all cases this disappeared as soon as the current intensity was reduced uncomfortable non-auditory sensation appeared (e.g. nausea, dizziness). Adverse effects related to the surgical placement of electrodes were only reported by Matsushima et al. [16] where perforation of the tympanic membrane was reported by 1 patient, however, it healed within 1 month.

\section{Non-invasive ear stimulation}

Demographic and baseline characteristics of studies investigating non-invasive ear stimulation are included in Table 3.

Among the 6 studies investigating non-invasive electrical stimulation, 4 used an electrode immersed inside the external ear canal filled with $0.9 \%$ saline solution, avoiding contact with the skin of the canal [30-32,35], while in 2 remaining studies the electrode was placed on the tympanic membrane $[21,25]$.

There were 4 studies investigating the effects of direct current $[30-32,35]$ and 2 of alternating current $[21,25]$. From studies that investigated the effects of direct current, 2 used current with positive polarity [30,35], 1 used negative polarity [31], and 1 used both positive and negative polarity [32]. A wide range of current intensities were used in different studies, ranging from 0.01 to $2.24 \mathrm{~mA}$. Frequency of the current varied between 62 and $8000 \mathrm{~Hz}$. There were 2 studies which used a single session for tinnitus suppression [25,31] and 4 multiple sessions [21,30,32,35]. Kuk et al. [25] reported a single session of 10 minutes duration. Mielczarek et al. [30,35] reported 15 sessions of 4 minutes duration applied 3-4 times a week. Daneshi et al. [21] 
reported 7 sessions of 30 minutes duration. Mielczarek et al. [32] did not specify the time of stimulation.

Efficacy of non-invasive ear stimulation: Of patients reporting improvement in their tinnitus, success of electrical ear stimulation varied between $32.8 \%$ [30] and $83.3 \%$ [31]. Similar to the studies using invasive ear stimulation, the definition of improvement varied between the non-invasive studies. There were 4 studies $[21,25,31,32]$ which defined improvement as suppression of tinnitus (i.e. reduction in tinnitus loudness, including the disappearance of tinnitus). Kuk et al. [25] reported that only $50 \%$ of patients $(5 / 10)$ who reported a reduction in tinnitus during the screening phase moved to the treatment phase. Those patients reported a reduction in tinnitus loudness and tinnitus annoyance of between $33 \%$ and $100 \%$. Mielczarek et al. [31] reported reduction in tinnitus loudness measured with VAS in 5/6 participants who had unilateral tinnitus when they received unilateral ear stimulation $(83.3 \%$, in two ears tinnitus disappeared completely); in comparison, they saw reductions in 7/12 ears of patients who had bilateral tinnitus after bilateral stimulation was given (58.3\%, in two ears tinnitus disappeared completely). Mielczarek et al. [32] reported a $75 \%$ success rate as indicated by reduction in tinnitus loudness measured with VAS. The reduction after stimulation, from 5.5 (SD 1.7) to 3.3 (SD 2.4), was statistically significant $(p<0.001)$. Daneshi et al. [21] reported tinnitus suppression in $62.5 \%$ of patients $(20 / 32)$.

There were 3 studies which reported changes in tinnitus distress as measured with a multi-item questionnaire. Daneshi et al. [21] reported a significant reduction in Tinnitus Questionnaire (TQ) scores from 50.7 (SD 19.3) to 39 (SD 20.4) after treatment ( $p=0.001$; paired $t$-test). Mielczarek et al. [30] and Mielczarek et al. [35] used a custom questionnaire designed by the authors, but based on the THI, to measure treatment effects. In the study by Mielczarek et al. [30] improvement in questionnaire scores was observed in 25 ears $(43.1 \%)$ in the group receiving electrical ear stimulation and in 20 ears (32.8\%) of ears receiving electrical ear stimulation combined with kinesitherapy. This improvement was stable at 30 and 90 days post intervention. Mielczarek and Olszewski [35] reported reduction of the questionnaire scores in 45 ears (37.8\%) in the intervention group and in 20 ears $(30.8 \%)$ in the placebo group. Further reduction in questionnaire scores was observed at 30 and 90 days post treatment $(p<0.05)$ in the intervention group.

It is worth noting that some studies also reported worsening of tinnitus after electrical ear stimulation. Mielczarek and Olszewski [35] reported deterioration of tinnitus in 9 out of 119 ears in the intervention group and 1 out of 65 ears in the placebo group. Mielczarek et al. [32] reported worsening of tinnitus in 2 out of 38 ears. No deterioration of tinnitus was observed in the remaining studies.

Type of current: All 6 studies reported reduction in tinnitus loudness or distress in a proportion of patients regardless of the type of current used. As different studies used different criteria to define the success rate, it is difficult to compare the effects of the different approaches. Studies using positive currents reported success rates of between $32.8 \%$ and $56.9 \%$; those using negative current $58.3 \%$ to $83.3 \%$; and 1 study using both approaches reported $75 \%$ success rate. Kuk et al. [25] investigated sine, rectangular, and triangular wave stimuli and concluded that triangular and square wave stimuli were more effective than sine waves.

Laterality of stimulation: None of the studies specifically looked at the effects of laterality of stimulation. However, the study by Mielczarek et al. [31] compared electrical ear stimulation in a group of patients with unilateral tinnitus and a group of patients with bilateral tinnitus. Unilateral stimulation was applied to the tinnitus ear for patients with unilateral tinnitus and bilateral stimulation for patients with bilateral tinnitus. No significant difference was observed between the two groups in terms of improvements in tinnitus loudness according to VAS scores $(p=0.7)$.

Intensity of the current: Mielczarek et al. [30], Mielczarek and Olszewski [35], Mielczarek et al. [31], and Mielczarek et al. [32] adjusted the intensity of the current according to the patients' tolerance. The patients received maximum well-tolerated intensity of the current. It ranged from 0.15 to $1.15 \mathrm{~mA}$ [30,35], 0.14-1.08 $\mathrm{mA}$ [31], and $0.01-2.24 \mathrm{~mA}$ [32]. There was no relation between the intensity of current (on average $0.47 \mathrm{~mA}$ ) used in ES and changes in the cortical activity recorded in the alpha band in the left central temporal and left frontal regions $(p>0.05)$ [31]. Moreover, there was correlation between the effectiveness of auditory system excitation (the presence of an auditory percept) and the current intensity in the tinnitus group (ES required higher intensities of current to evoke sound perception $(p<0.003)$ compared to the healthy subject group). Moreover, there was no correlation between hearing threshold and current intensity needed to evoke AP during electrical stimulation [32]. Daneshi et al. [21] performed stimulation using a current range of 60 to $500 \mu \mathrm{A}$. Kuk et al. [25] found that an intensity range of 4-900 $\mu \mathrm{A}$, depending on stimulus frequency, was the optimal current level for tinnitus suppression.

Frequency of stimulation: Different studies have tested stimulation frequencies between 62 and $8000 \mathrm{~Hz}$. Out of 6 studies, 3 investigated tinnitus suppression using a wide range of current frequencies $(250-8000 \mathrm{~Hz})[30,32,35]$ However, in the first 2, ES was performed using a frequency adapted to the tinnitus pitch. In the third study, ES was performed at each frequency from the given range, which had a good therapeutic effect in $75 \%$ of the tinnitus ears. Kuk et al. [25] used a wider range of frequencies $(62-8000 \mathrm{~Hz})$ with a positive effect in 5 of 10 patients. Mielczarek et al. [31] applied a single frequency of stimulation $(250 \mathrm{~Hz})$ and obtained improvement in tinnitus (loudness reduction in VAS) in 12 of 18 tinnitus ears. Daneshi et al. [21] reported that, in general, a current frequency of less than $600 \mathrm{~Hz}$ was more effective in giving tinnitus suppression than higher frequency stimuli.

Duration of tinnitus suppression: Duration of tinnitus suppression varied across the studies. There were 2 studies assessing the long-term effect of ES $[30,35]$. These studies involved a sequence of 15 applications of ES as a treatment and follow-ups after 30 and 90 days. Directly after the treatment the improvement rate (based on questionnaires) ranged from $32.8 \%$ to $43.1 \%$ and increased after 30 days from the end of treatment to $56.9 \%$ [30]. There 
was a high percentage of tinnitus disappearance directly after an ES cycle (39.7\%), which decreased with time (90 days) to $15.5 \%$ [30]. In the study with a placebo group, the percentage of tinnitus disappearance differed significantly: $33.6 \%$ (study group) vs $6.1 \%$ (placebo group) after the end of treatment [35]. In the study by Daneshi et al. [21], 32 patients (62.5\%) experienced tinnitus suppression, however, this occurred only immediately after the electrical stimulation was applied. Kuk et al. [25] report tinnitus suppression lasting from $40 \mathrm{~s}$ to $4 \mathrm{~h}$.

Adverse effects: There were 3 of 6 studies which did not report any adverse effects upon electrical stimulation [21,31,35]; 3 studies did report adverse effects, mainly pain or unpleasant sensations $[25,31,32]$. The studies followed the same strategy of increasing the current intensity to the maximum well-tolerated level (the level without pain or unpleasant sensation). Mielczarek et al. [32] reported temporary pain sensations in persons from both groups: 25 patients (51\%) in the tinnitus group and 14 individuals $(41 \%)$ in the healthy subjects group. In all cases, pain disappeared as soon as the current intensity was smoothly decreased.

\section{Discussion}

This paper is a review of the literature on electrical ear stimulation in tinnitus treatment. ES treatment has been used since the 1970s and different techniques have been explored. A low level of evidence is available in terms of the advantages of a particular technique or stimulation parameter due to the non-standardised methodology of the studies available. The difficulties in comparing the effectiveness of the studies are related to many factors which are discussed below. One of them is variability in outcome measures, including different definitions of treatment success and limited use of standardised and validated outcome measures.

\section{Invasive vs non-invasive techniques}

Different sites of the auditory structures have been stimulated via two different approaches. Non-invasive stimulation has been performed through the external ear canal with the use of transmission methods (active electrode dipped in saline in the external auditory canal or stimulating the tympanic membrane). However, invasive stimulations require a surgical procedure: tympanic membrane incision or puncture in order to reach the round window or promontory. This complication was probably the factor determining the limited number of invasive stimulation studies which investigated the effects of multiple stimulation sessions.

Considering the site of stimulation, round window stimulation seems the most justified from an anatomical point of view (it is the smallest distance from the desired effector, the cochlea). However, in terms of the reported effectiveness and size of the study group, promontory stimulation appears more effective (tinnitus suppression in $86 \%$ of patients for treatment of a few hours to a week, based on patients' report) [34]. The effectiveness of non-invasive methods appears to be about the same, with no clear indication that one approach is more effective than another.
However, one paper showed an effectiveness of $83.3 \%$ improvement based on VAS scores for loudness [31]. Importantly, the advantage of non-invasive techniques is the possibility of having multiple ES sessions without potential harm to the tympanic membrane and the option of performing the treatment as an outpatient procedure. Thus, further research should include an investigation of noninvasive techniques.

\section{Stimulating parameters}

Both DC and AC were used in the invasive and non-invasive procedures. In the former, early papers showed that tinnitus suppression was obtained for positive currents, whereas negative currents elicited auditory sensations [19]. Non-invasive stimulations showed similar results for both currents and one recent study using both positive and negative currents reached an efficacy of $75 \%$ [32]. Based on the analysed papers, there seems to be no evidence for the higher effectiveness of a specific type of current. Although research using DC stimulation has indicated no harmful effects, and unchanged or even improved hearing status in tinnitus patients $[30,35]$, safety issues - especially in case of prolonged DC stimulation - need to be carefully investigated.

The choice of stimulating frequency differed across all studies. Some studies used low frequencies (e.g. $10 \mathrm{~Hz}$ ) which can be justified by the hypothesis that these frequencies stimulate the whole of the hearing range (from the cochlear base to the apex) evoking a travelling wave across the entire cochlea with a maximum at a specific stimulating frequency. Some other studies adapted a stimulating frequency to the tinnitus pitch, or used a wide range of frequencies. Based on the selected studies, low stimulating frequencies (below $1000 \mathrm{~Hz}$ ) were used most often and they appeared to give better results than higher frequencies.

The intensity of the current differed according to the applied techniques (the invasive approach used lower intensities) and the study. The reported unpleasant effects of stimulation, such as pain, suggest that this parameter might need adjustment based on the individual patient's feedback, rather than arbitrary values.

Duration of ES, like other parameters of stimulation, varied. Most of the invasive studies used one session, due to the need for repeated surgery to apply multiple sessions. Nevertheless, comparing one-session studies with multiple-session studies, there is still no obvious advantage of one approach over the other. The exception is the Mielczarek and Olszewski study [35] which showed improved and consolidated effect of repeated sessions of ES observed 1 month after the end of treatment.

\section{Future directions}

A major factor limiting assessment of the efficacy of electrical ear stimulation in both techniques (invasive and non-invasive) is outcome measure. Studies included in this review differed between each other in terms of outcome measures, which makes them difficult to compare reliably. This was the major limitation of the present work, which might be solved by the use of validated, world-wide 
recognised questionnaires to assess the results of interventions. The other is a lack of randomised, placebo controlled trials (RCTs). In order to assess the true efficacy of a given method, comparisons with shams are indispensable, although there are some limitations and methodological difficulties highlighted when placebo groups for ES are used (e.g. some skin sensations during ES [36,37]).

Given that studies to date have reported success in tinnitus suppression with both invasive and non-invasive methods, future research for ear ES in tinnitus treatment should in the first instance focus on non-invasive methods that do not require surgery. However, invasive methods might be used for patients who do not respond to treatment with non-invasive stimulation or have specific indications for this type of treatment.

\section{Conclusions}

Based on the reviewed literature we can conclude that in terms of different methods, stimulation parameters, and effectiveness, there is no clear advantage of one stimulation condition over the other. It leads to the further conclusion that the present body of evidence is not sufficient to formulate recommendations for ear ES parameters. This is due to (a) methodological limitations (all 20 studies differed from one another in terms of application of electrical stimulation in both invasive and noninvasive technique); (b) use of non-standardised outcome measures; (c) lack of control or placebo groups; (d) lack of studies with longer follow-up periods which are necessary to prove the therapeutic effect of ES. Future studies should specifically concentrate on defining optimal stimulation parameters and should focus on standardising existing study protocols for data acquisition as well as data assessment. There is a need for stronger methodology, with particular stress on the use of standardised validated outcome measures and better study design (including randomised control trials).

\section{Acknowledgements}

This project has received funding from the European Union's Horizon 2020 research and innovation programme (Marie Skłodowska-Curie grant agreement number 722046).

MS is funded through the British Tinnitus Association Senior Research Fellow/Head of Research fellowship. The views expressed are those of the authors and not necessarily those of the NIHR, the NHS, or the Department of Health and Social Care.

\section{References}

1. Langguth B, Kreuzer PM, Kleinjung T, De Ridder D. Tinnitus: causes and clinical management. Lancet Neurol, 2013; 12(9): 920-30.

2. Axelsson A, Ringdahl A. Tinnitus: a study of its prevalence and characteristics. Br J Audiol, 1989; 23(1): 53-62.

3. Heller AJ. Classification and epidemiology of tinnitus. Otolaryngology Clin North Am, 2003; 36(2): 239-48.

4. Kennedy V, Wilson C, Stephens D. Quality of life and tinnitus. Audiol Med, 2009; (1): 1-12

5. Nondahl D, Cruickshanks, K, Dalton D et al. The impact of tinnitus on quality of life in older adults. J Am Acad Audiol, 2007; Mar; 18(3): 257-66

6. Ziai K, Moshtaghi O, Mahboubi H, Djalilian HR. Tinnitus patients suffering from anxiety and depression: a review. Int Tinnitus J, 2017; 21(1): 68-73.

7. Hall DA, Fackrell K, Li AB et al. A narrative synthesis of research evidence for tinnitus-related complaints as reported by patients and their significant others. Health Qual Life Outcomes, 2018; 16(1): 61.

8. Haider, H, Bojić T, Ribeiro S, Paço J, Hall D, Szczepek A. Pathophysiology of subjective tinnitus: triggers and maintenance. Front Neurosci, 2018; 12: 866

9. Eggermont JJ, Roberts LE. The neuroscience of tinnitus: understanding abnormal and normal auditory perception. Front Syst Neurosci, 2012; 6: 1-4.

10. Eggermont JJ, Tass PA. Maladaptive neural synchrony in tinnitus: origin and restoration. Front Neurol, 2015; 6: 1-17.

11. Henry J, Roberts L, Caspary D, Theodoroff S, Salvi R. Underlying mechanisms of tinnitus: review and clinical implications. J Am Acad Audiol, 2014; Jan; 25(1): 5-22.

12. Hoare DJ, Adjamian P, Sereda M. Electrical stimulation of the ear, head, cranial nerve, or cortex for the treatment of tinnitus: a scoping review. Neural Plast, 2016; 2016:5130503.
13. Ren T, Nuttall AL. Extracochlear electrically evoked otoacoustic emissions: a model for in vivo assessment of outer hair cell electromotility. Hear Res, 1995; 92: 178-83.

14. Nuttall AL, Ren T. Electromotile hearing: evidence from basilar membrane motion and otoacoustic emissions. Hear Res, 1995 Dec; 92(1-2): 170-7.

15. Aran JM, Cazals Y. Electrical suppression of tinnitus. Ciba Found Symp, 1981; 85: 217-31.

16. Matsushima J, Sakai N, Sakajiri M, Miyoshi S, Uemi N, Ifukube $\mathrm{T}$. An experience of the usage of electrical tinnitus suppressor. Artif Organs, 1996; 20(8): 955-8.

17. Okusa M, Shiraishi T, Kubo T, Matsunaga T. Tinnitus suppression by electrical promontory stimulation in sensorineural deaf patients. Acta Otolaryngol Suppl, 1993; 113(501): 54-8.

18. Zeng FG, Djalilian H, Lin H. Tinnitus treatment with precise and optimal electric stimulation: opportunities and challenges. Curr Opin Otolaryngol Head Neck Surg, 2015; Oct; 23(5): 382-7.

19. Cazals Y, Negrevergne M, Aran JM. Electrical stimulation of the cochlea in man: hearing induction and tinnitus suppression. J Am Audiol Soc, 1978; 3(5): 209-13.

20. Cazals Y, Rouanet JF, Negrevergne M, Lagourgue P. First results of chronic electrical stimulation with a round-window electrode in totally deaf patients. Arch Otorhinolaryngol, 1984; 239(3): 191-6.

21. Daneshi A, Mahmoudian S, Farhadi M, Hasanzadeh S, Ghalebaghi B. Auditory electrical tinnitus suppression in patients with and without implants. Int Tinnitus J, 2005; 11(1): 85-91.

22. Di Nardo W, Cianfrone F, Scorpecci A, Cantore I, Giannantonio S, Paludetti G. Transtympanic electrical stimulation for immediate and long term tinnitus suppression. Int Tinnitus J, 2009; 15(1): 100-6.

23. Graham JM, Hazell JW. Electrical stimulation of the human cochlea using a transtympanic electrode. Br J Audiol, 1977; May; 11(2): 59-62. 
24. Hazell JW, Jastreboff PJ, Meerton LE, Conway MJ. Electrical tinnitus suppression: frequency dependence of effects. Audiology, 1993; 32(1): 68-77.

25. Kuk FK, Tyler RS, Rustad N, Harker LA, Tye-Murray N. Alternating current at the eardrum for tinnitus reduction. J Speech Hear Res, 1989; 32(2): 393-400.

26. Matsushima JI, Fujimura H, Sakai N et al. A study of electrical promontory stimulation in tinnitus patients. Auris Nasus Larynx, 1994; 21(1): 17-24.

27. Perez R, Shaul C, Vardi M, Muhanna N, Kileny P, Sichel J. Multiple electrostimulation treatments to the promontory for tinnitus. Otol Neurotol, 2015; Feb; 36(2): 366-72.

28. Watanabe K, Okawara D, Baba S, Yagi, T. Electrocochleographic analysis of the suppression of tinnitus by electrical promontory stimulation. Audiology, 1997; May-Jun; 36(3): 147-54.

29. Rubinstein JT, Tyler RS, Johnson A, Brown CJ. Electrical suppression of tinnitus with high-rate pulse trains. Otol Neurotol, 2003; 24(3): 478-85.

30. Mielczarek M, Konopka W, Olszewski J. The application of direct current electrical stimulation of the ear and cervical spine kinesitherapy in tinnitus treatment. Auris Nasus Larynx, 2013; 40(1): 61-5.
31. Mielczarek M, Michalska J, Polatynska K, Olszewski J. An Increase in alpha band frequency in resting state EEG after electrical stimulation of the ear in tinnitus patients: a pilot study. Front Neurosci, 2016; 10: 453.

32. Mielczarek M, Norena A, Schlee W, Olszewski J. Excitation of the auditory system as a result of non-invasive extra-cochlear stimulation in normal subjects and tinnitus patients. Front Neurosci, 2018; $12: 146$.

33. Aran JM. Electrical stimulation of the auditory system and tinnitus control. J Laryngol Otol Suppl, 1981; 153-61.

34. Konopka W, Zalewski P, Olszewski J, Olszewska-Ziaber A, Pietkiewicz P. Tinnitus suppression by electrical promontory stimulation (EPS) in patients with sensorineural hearing loss. Auris Nasus Larynx, 2001; 28(1): 35-40.

35. Mielczarek M, Olszewski J. Direct current stimulation of the ear in tinnitus treatment: a double-blind placebo-controlled study. Eur Arch Oto-Rhino-Laryngology, 2014; 271(6): 1815-22.

36. Dobie RA, Hoberg KE, Rees TS. Electrical tinnitus suppression: a double-blind crossover study. Otolaryngol Head Neck Surg, 1986; 95(3 Pt 1): 319-23.

37. Kapkin O, Satar B, Yetiser S. Transcutaneous electrical stimulation of subjective tinnitus. A placebo-controlled, randomized and comparative analysis. ORL J Otorhinolaryngol Relat Spec, 2008; 70(3): 156-61. 